DOMINIKA GRABIEC

INSTYTUT SZTUKI, POLSKA AKADEMIA NAUK

\title{
POLSKI PRZEKŁAD ARS ET PRAXIS MUSICA ZYGMUNTA LAUKSMINA Z I798 ROKU I PROBLEMY NAUCZANIA ŚPIEWU CHORAŁOWEGO NA ZIEMIACH POLSKICH W XVII I XVIII WIEKU
}

\begin{abstract}
VU spisie rękopisów muzycznych zachowanych w wybranych bibliotekach klaszW tornych w Polsce, sporządzonym przez ks. Romana Nira, wśród muzykaliów z Biblioteki oo. Cystersów w Szczyrzycu pod sygnaturą S.II.8/2 odnotowany został, niezauważony do tej pory przez muzykologów, polskojęzyczny podręcznik do nauki śpiewu chorałowego: Nauka y praktyka muzyczna do używania uczacey się mtodzi $w$ Kollegiach Societatis Jesu za pozwoleniem starszych przetożona $w$ Wilnie. Przedrukowana w Drukarni Akademickiey. R.P. I693 a teraz świeżo z tacińskiego języka na Polski przettumaczona Roku Pańskiego I798. W Limanowey przepisana na prośbę P. Kantego. Z krótkiego opisu katalogowego wynika, że rękopis liczy czternaście kart o wymiarach I6 x I2 cm, w oprawie kartonowej z przełomu XVIII i XIX w., a więc sporządzonej w tym samym czasie, co sam manuskrypt, oraz że zawiera polskie dopiski i przykłady muzyczne zapisane neumami gotyckimi ${ }^{\mathrm{T}}$.
\end{abstract}

\section{AUTORSTWO ORYGINALNEGO TRAKTATU ŁACIŃSKIEGO}

Choć w opisie brak nazwiska autora łacińskiego oryginału, to problem identyfikacji wileńskiego druku udało się szybko rozwiązać dzięki opublikowanym w Polsce pracom litewskiej muzykolożki, Jūratė Trilupaitiené, poświęconym życiu muzycznemu w Akademii Wileńskiej w XVII w. oraz działalności jezuity Zygmunta Lauksmina,

I Zob.: Roman Nir, „Rękopiśmienne zabytki muzyczne w niektórych polskich bibliotekach klasztornych, Muzyka 23 (I978) nr 3, s. I04. Zob. też: Roman Nir, „Rękopisy muzyczne w Bibliotece oo. Cystersów w Szczyrzycu”, Archiwa, Biblioteki i Muzea Kościelne 37 (1978), s. 245. 
autora m.in. właśnie podręczników muzycznych ${ }^{2}$. Zgodność tytułu, daty i miejsca wydania, zamieszczonych na stronie tytułowej wspomnianego polskiego przekładu, z rokiem wydania i tytułem podręcznika Lauksmina Ars et praxis musica, były jasną wskazówką, że mamy do czynienia z tłumaczeniem tego właśnie dzieła, a porównanie obu tekstów potwierdziło wstępne przypuszczenia ${ }^{3}$. Dokładną analizę przekładu ułatwiła współczesna edycja faksymilowa podręcznika, w której wykorzystano egzemplarz druku z I693 r. (il. I), czyli tego samego wydania, którym dysponował tłumacz, a także współczesne tłumaczenie traktatu i jego monograficzne opracowanie przygotowane przez Agnieszkę Krzepkowską ${ }^{4}$.

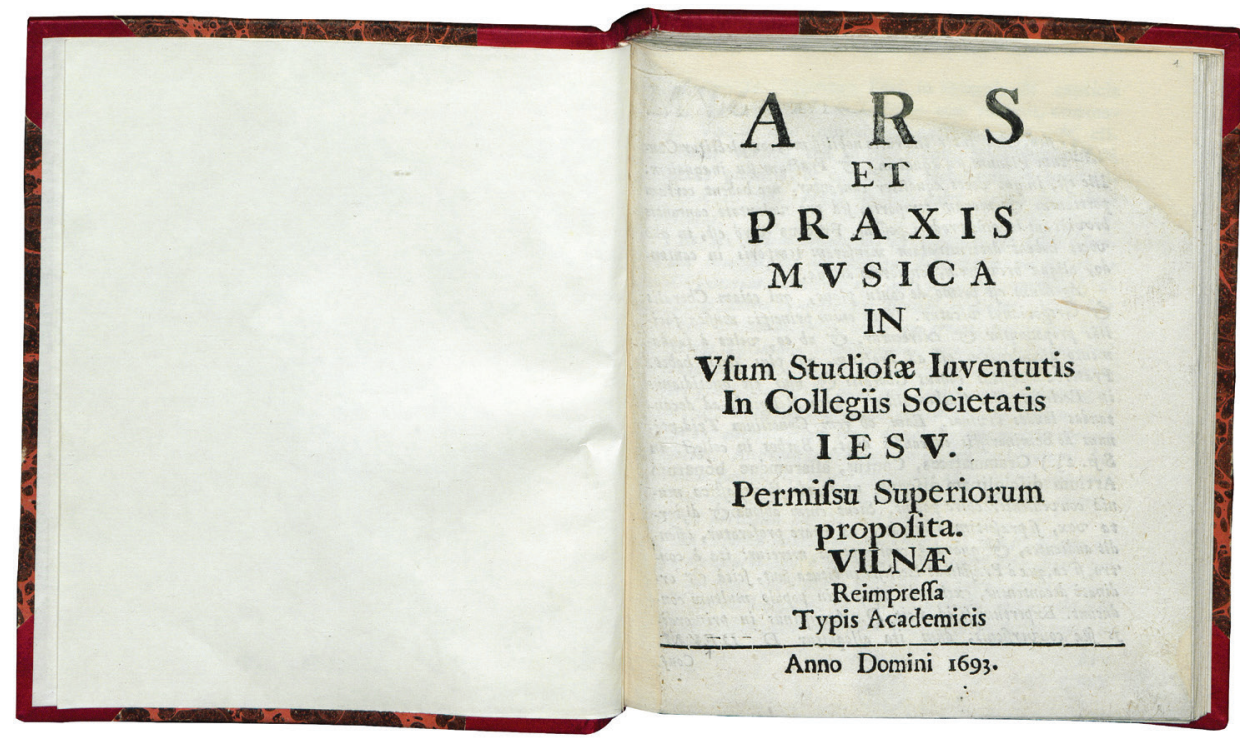

Il. I. Strona tytułowa druku Ars et praxis musica, 1693, Biblioteka Narodowa, Warszawa, sygn. SD XVII.3.882 adl., fot. Polona

Autor traktatu, występujący w źródłach jako Sigismundus Lauxmin, urodził się w I596 r., a zmarł II IX I670 r. w Wilnie. Studiował filozofię na Akademii Wileńskiej, nauczał w seminariach i kolegiach jezuickich, a następnie odbył studia teologiczne na tej samej uczelni. Od I635 r. był jej profesorem, zaś w I642 r. zdobył tytuł doktora

2 Zob.: Jūratė Trilupaitienė, „Zygmunt Lauksmin w życiu muzycznym Akademii Wileńskiej”, Muzyka 36 (I99I) nr I, s. IOI-II5; Sigismundus Lauxmin (I596-I670), Ars et praxis musica. Graduale pro exercitatione studentium. Antiphonale ad Psalmos, wyd. Jūratė Trilupaitienè, Warszawa 2016 (= Fontes musicae in Polonia, B/I).

3 W tym miejscu pragnę serdecznie podziękować o. Dominikowi Chucherowi, opatowi klasztoru oo. Cystersów w Szczyrzycu za udostępnienie skanów rękopisu oraz zgodę na ich wykorzystanie do celów naukowych.

4 Por.: Sigismundus Lauxmin (I596-I670), s. I-I6; Agnieszka Krzepkowska, Zygmunt Lauxmin - traktat "Ars et praxis musica”, Warszawa 2012. 
teologii. W kolejnych latach pełnił również funkcje dydaktyczne i kierownicze w kilku kolegiach jezuickich. W jego spuściźnie piśmienniczej znalazły się opracowania poświęcone retoryce, m.in. wielokrotnie wznawiana w różnych drukarniach polskich i europejskich Praxis oratoria sive praecepta artis rhetoricae (pierwodruk: Braniewo I648), podręcznik do nauki greki Epitome institutionum linguae graecae (Wilno 1655), a także trzy wydane anonimowo podręczniki do nauki śpiewu chorałowego: Ars et praxis musica (Wilno 1667, 1669, I693), Graduale pro exercitatione studentium (Wilno 1667, I693, 1742) oraz Antiphonale ad psalmos, iuxta ritum S. Romanae ecclesiae, decantandos necessarium (Wilno I667, I694, I742) 5

\section{UKŁAD I ZAWARTOŚĆ TRAKTATU ARS ET PRAXIS MUSICA}

Tomy Graduale oraz Antiphonale zawierają wyłącznie śpiewy liturgiczne ${ }^{6}$, natomiast treści teoretyczno-muzyczne zostały wyłożone w traktacie, który rozpoczyna się trzystronicowym wstępem „Ad Philomusum”. Lauksmin objaśnił w nim najpierw podstawowe różnice między cantus planus i cantus fractus oraz uzasadnił potrzebę rozpoczynania nauki muzyki od śpiewu chorałowego, który ma być starannie wykonywany, aby rzeczywiście oddawał chwałę Bogu i ożywiał pobożność wiernych7. Dalej autor wskazał dwie przeszkody w nauce muzyki: brak dobrych nauczycieli i rozpoczynanie nauki od trudniejszego śpiewu fraktowanego oraz brak podręczników, na który starał się odpowiedzieć, pisząc własny traktat. Wspomniał tu także o ojcu jezuicie, który przekazał pewną sumę pieniędzy dla kolegium kroskiego, w którym Lauksmin przez kilka lat pełnił funkcję rektora aż do I665 $\mathrm{r}^{8}$, na książki i pensję nauczyciela muzyki9.

Rozdział pierwszy poświęcony jest wspólnym zasadom śpiewu chorałowego (cantus planus) i fraktowego (cantus fractus). Autor objaśnił w nim najpierw zasady stosowania sylab solmizacyjnych i zaproponował ćwiczenia pomocne w zapamiętaniu odległości pomiędzy dźwiękami, nie wprowadzając jednak pojęcia „interwałów” ani ich nazw. Opanowanie solmizacji miało umożliwić następnie podkładanie pod zapis muzyczny tekstów konkretnych śpiewów.

5 Por.: J. Trilupaitienè, „Zygmunt Lauksmin”, s. IOI-IO2. Zob. też: Sigismundus Lauxmin (I596-I670), s. V-VI; Anna Królikowska, Profesorowie jezuickich seminariów nauczycielskich od XVI do XVIII wieku. Stownik biograficzny, Kraków 20I7, s. 97-IOO; A. Krzepkowska, Zygmunt Lauksmin, s. 3I-38.

6 Zob.: Sigismundus Lauxmin (I596-1670), s. 17-163.

7 Treść traktatu przedstawiona została szczegółowo przez Agnieszkę Krzepkowską, tutaj jednak zamieszczamy dla porząadku krótkie streszczenie jego zawartości, które może stanowić punkt odniesienia dla zagadnień poruszanych w dalszej części artykułu. Pełne omówienie oraz tłumaczenie traktatu znajduje się w: A. Krzepkowska, Zygmunt Lauksmin, s. 65-90.

8 Por.: ibid., s. 34 .

9 Nauka śpiewu odbywała się w niższych klasach gimnazjum, była obowiązkowa i poświęcano na nią pół godziny po zakończeniu innych lekcji. Zajęcia prowadził świecki nauczyciel, zazwyczaj zatrudniony jednocześnie w bursie muzycznej, ale w obecności jezuity, zob.: A. Królikowska, Profesorowie jezuickich seminariów, s. I5. 
W kolejnym akapicie omówione zostały bardzo krótko podstawowe elementy zapisu muzycznego, takie jak linie i pola, neumy używane w notacji chorałowej (z przykładem graficznym punctum i virgi) oraz klucz C. Objaśnieniu towarzyszy przykładowy zapis skali heksachordalnej na pięciolinii oraz propozycja wprawek solmizacyjnych (il. 2). Dopiero po ich opanowaniu Lauksmin zaleca ćwiczenia z podkładaniem tekstu, załączając w tym celu zapis śpiewu $O$ adoranda Trinitas i objaśniając sposób interpretacji neum z ogonkiem i bez, a także znaków dodatkowych, takich jak daszek umieszczony nad neumą i kropka przy nucie.

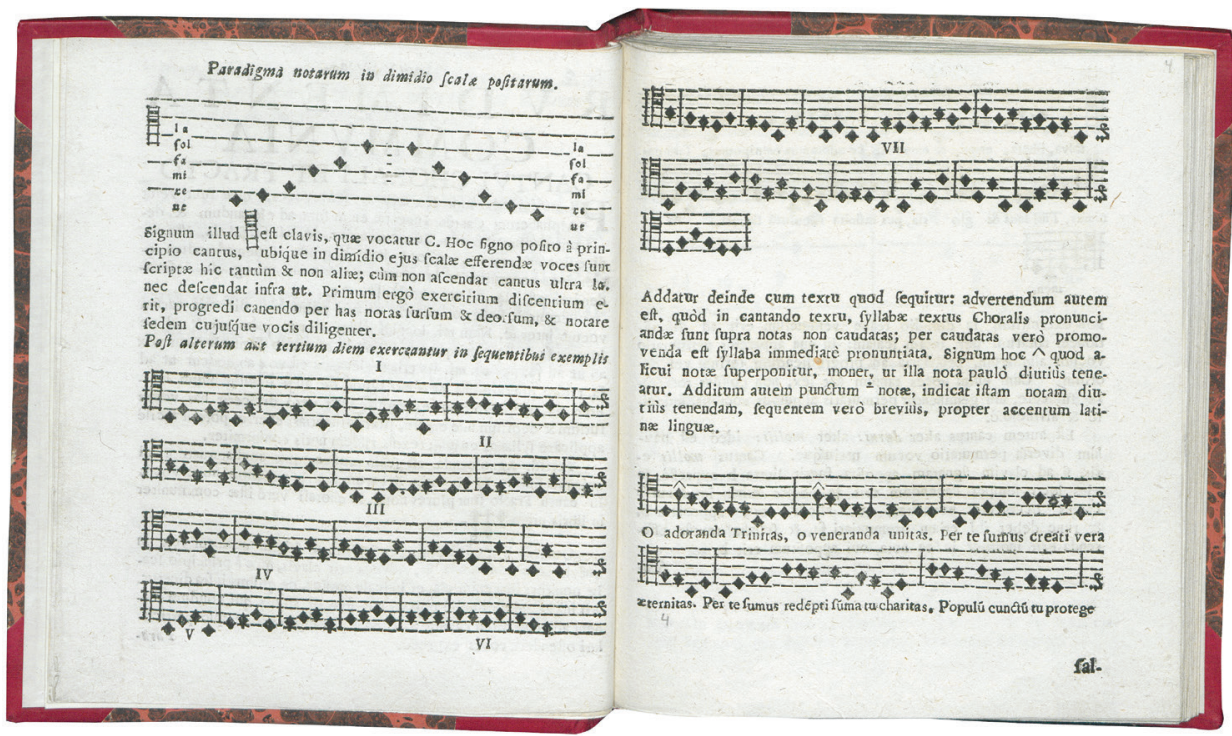

Il. 2. Ćwiczenia wokalne w pierwszym rozdziale Ars et praxis musica, I693, Biblioteka Narodowa, Warszawa, sygn. SD XVII.3.882 adl., fot. Polona

W dalszej części rozdziału jezuita objaśnia, co należy zrobić, jeśli ambitus melodii przekracza heksachord i brakuje kolejnych sylab do nazwania wyższych lub niższych dźwięków ${ }^{\mathrm{IO}}$. W takim przypadku system heksachordalny wiązał się z koniecznością opanowania ściśle określonych zasad poprawnej podmiany sylab solmizacyjnych, różnych w przypadku śpiewu durus (twardego) i mollis (miękkiego) ${ }^{\mathrm{II}}$. Autor objaśnia pokrótce te zasady, a przy okazji znaczenie bemola i kasownika, dołączając do tekstu dwa przykłady muzyczne skali mollis i durus, ilustrujące reguły wymiany sylab i uła-

Io Autor posługuje się w swoim traktacie heksachordalnym system solmizacyjnym, ukształtowanym w średniowieczu i wciąż powszechnie stosowanym w Polsce w XVII, a nawet jeszcze w XVIII wieku.

II Lauksmin nie wprowadził pojęcia śpiewu naturalis, które w tym miejscu pojawia się w wielu traktatach chorałowych, zob.: Elżbieta Witkowska-Zaremba, Ars musica w krakowskich traktatach muzycznych XVI wieku, Kraków 1986, s. I40-I48. 
twiające ich zapamiętanie ${ }^{\mathrm{I} 2}$. Na końcu rozdziału zamieszcza fragmenty kilku śpiewów (Veni Sancte Spiritus, Sit nomen Domini, Sub Tuum Praesidium, Sancti Dei omnes, Qui passus es, Tibi laus, Tibi gloria) mające posłużyć uczniom do wyćwiczenia wyłożonych w rozdziale zasad. Zaleca przy tym, by najpierw śpiewać je solmizacją, a dopiero później podkładać tekst, a także przypomina o sposobie interpretacji rytmicznej neum, co ukazuje jego troskę o właściwą metodykę nauczania.

W rozdziale drugim omówione zostały w skrócie claves, czyli klucze, te zapisywane na systemie liniowym (signatae), czyli C i F oraz niezapisywane (occultae) ${ }^{\mathrm{I}}$. W przypadku kluczy oznaczanych na pięciolinii, autor zaprezentował ich formę graficzną (także klucza C z bemolem w cantus mollis), wyjaśnił ich funkcję i wskazał na możliwość zmiany położenia na pięciolinii w celu uniknięcia stosowania większej liczby linii dodanych dolnych lub górnych w przypadku melodii opadających w dół lub wznoszących się w górę. Na koniec jeszcze raz przypomniał o konieczności starannego wyćwiczenia podanych zasad, by móc później wykonywać śpiewy zamieszczone w księgach liturgicznych.

Ostatni i najkrótszy rozdział dotyczy cantus fractus. Lauksmin wyjaśnia, że śpiew ten dodaje do śpiewu chorałowego tactus, czyli rytm i zróżnicowaną długość dźwięków oraz pauz między nimi, co wiąże się ze stosowaniem większej liczby różnych nut w zapisie muzycznym, których jednak autor nie przedstawia. Dodaje tylko, że w cantus fractus stosowane są te same klucze, co w śpiewie chorałowym, ale poniewaź śpiew ten jest wielogłosowy, to są one rozmieszczone w różnych miejscach na pięciolinii, dla każdego głosu oddzielnie, o czym jednak zamierzał napisać w innym miejscu ${ }^{\mathrm{I4}}$. Po tym krótkim objaśnieniu następuje końcowa inwokacja oddająca chwałę Bogu i Królowej Niebios.

\section{PRZEZNACZENIE I RECEPCJA TRAKTATU LAUKSMINA}

Dwukrotne wznowienia druków muzycznych świadczą o tym, że długo cieszyły się one popularnością i były wykorzystywane w praktyce. Według Jūratė Trilupaitienė podręcznik Ars et praxis musica mógł zostać przygotowany na potrzeby wykładów prowadzonych w katedrze muzyki działającej na Akademii Wileńskiej od I667 roku. Litewska badaczka przypuszcza, że prowadzenie wykładów mogło zostać powierzone

Zasady wymiany sylab solmizacyjnych, czyli „mutacji”, w heksachordach duralis i mollis szczegółowo objaśnione zostały m.in. w: Wojciech Domański, „Teoria muzyki w traktatach chorałowych Sebastiana z Felsztyna", w: Musica Medii Aevi, red. Jerzy Morawski, t. 7, Kraków 1986, s. 216-224; E. Witkowska-Zaremba, Ars musica, s. 150-169.

I3 Szersze znaczenie tych terminów, ukształtowanych przez średniowiecznych teoretyków muzyki, zostało szczegółowo wyjaśnione w: W. Domański, „Teoria muzyki”, s. 215-216; E. Witkowska-Zaremba, Ars musica, s. I32-I40; Marcin Kromer. Musicae elementa, wyd. i przekł. polski Elżbieta Witkowska-Zaremba, Warszawa 2019 (= Monumenta Musicae in Polonia, seria C Tractatus de musica), s. 67-68.

I4 Nie zachowały się żadne informacje na temat innego traktatu Lauksmina, więc prawdopodobnie druga część objaśniająca zasady cantus fractus nigdy nie powstała. 
Lauksminowi, choć nie zachowały się źródła, które mogłyby to potwierdzić. Prowadzone w katedrze zajęcia miały przygotowywać studentów między innymi do śpiewu podczas liturgii sprawowanej w jezuickim kościele akademickim ${ }^{15}$. Jest jednak dużo bardziej prawdopodobne, że traktat napisany został dla uczniów kolegium jezuickiego w Krożach, jak słusznie stwierdza Agnieszka Krzepkowska. Wskazuje na to przede wszystkim już sam tytuł oraz fragment wstępu:

Szczodrobliwość jednego z ojców naszego Towarzystwa dała nam w kolegium kroskim możność pokonania tych przeszkód. Przekazał on ze swej ojcowizny 800 florenów, z których część przeznaczona byłaby na wynagrodzenia dla nauczającego, część zaś na zakup książek dla uczących się. Ogłaszamy więc tę łatwą metodę nauczania i aby brakowi podręczników zaradzić, chcemy w zwięzłej formie przedstawić to, co zwykło się śpiewać w kościele świętym, aby mogli się z tego uczyć ci, co zechcą i aby sami, z własnej woli, kiedy zechcą, śpiewać mogli ${ }^{16}$.

Także treść dzieła sugeruje, że przeznaczone było ono raczej dla uczniów, niż studentów Akademii. Wykład śpiewu chorałowego ograniczony został tylko do najbardziej podstawowych treści, mieszczących się zwykle w kilku wstępnych rozdziałach innych znanych traktatów i podręczników chorałowych. Lauksmin pominął w swoim podręczniku trudniejsze zagadnienia i terminy, których opanowanie wymagało większej ilości czasu, nawet te, które wydają się dziś niezbędne do opanowania podstaw śpiewu, jak np. nazewnictwo interwałów. Nie wprowadził również zagadnienia tonów kościelnych i dyferencji psalmowych, które znajdowały się w większości znanych prac teoretycznych, opisał natomiast i wyjaśnił znaczenie najprostszych nawet graficznych znaków muzycznych, takich jak neumy proste, linie i pola, czy klucze. Jego definicje terminów i zasad muzycznych są niekiedy tak zwięzłe, że wbrew intencjom autora, mogło to utrudniać zrozumienie niektórych fragmentów tekstu, np. tych dotyczących reguł wymiany sylab w śpiewie durus i mollis. Pominięte zostały też często zamieszczane we wstępach do podobnych dzieł czysto teoretyczne, spekulatywne rozważania na temat pochodzenia muzyki i jej oddziaływania na ludzi i zwierzęta, wynalazców instrumentów muzycznych, a także różnych podziałów teoretycznych muzyki. Wykład ten przeznaczony był dla uczniów stawiających dopiero pierwsze kroki i ograniczał się do absolutnie najbardziej podstawowych wiadomości potrzebnych do opanowania w praktyce śpiewu chorałowego.

\section{ARS ET PRAXIS MUSICA W KONTEKŚCIE INNYCH POLSKICH TRAKTATÓW CHORAŁOWYCH}

Tekst traktatu jest prawdopodobnie kompilacją wiedzy własnej Lauksmina oraz informacji zawartych w dziełach innych teoretyków muzyki. Brak informacji o autorstwie w nagłówku polskojęzycznej wersji podręcznika przestaje dziwić, jeśli spoj-

I5 Por.: J. Trilupaitiené, „Zygmunt Lauksmin”, s. I03-IO7.

I6 A. Krzepkowska, Zygmunt Lauxmin, s. 63, 68, 76. 
rzymy na stronę tytułową druku, gdzie również nie widnieje żadne nazwisko. Decyzja o anonimowości publikacji wynikała prawdopodobnie właśnie z tego faktu, że traktat nie był dziełem oryginalnym, a w przypadku tego rodzaju prac jezuici zwyczajowo nie umieszczali własnego nazwiska ${ }^{17}$. Z kolei po upływie ponad stu lat od publikacji druku ustalenie autora, nawet jeśli za życia był w kręgu jezuickim powszechnie znany, stanowiło już z pewnością dużą trudność, zwłaszcza dla czytelników nie związanych ze środowiskiem wileńskim, jego tradycjami i historią. Agnieszka Krzepkowska w swojej monografii zasugerowała, że mogło być to jednak dzieło oryginalne, gdyż nie odnalazła wśród znanych dziś szesnasto- i siedemnastowiecznych traktatów muzycznych tekstu, który byłby do niego choćby zbliżony pod względem formy i treści. Stwierdziła również, że na tle innych podręczników wileński wykład zasad muzyki przedstawia się jako nowatorski pod względem metodycznym i dzięki swojej zwięzłości odbiegający od innych ówczesnych traktatów, według niej „zawiłych”, bazujących na wzorcach średniowiecznych i renesansowych, choć sama następnie stwierdza, że „prototypów Ars należałoby szukać w średniowieczu” ${ }^{18}$. Trudno zgodzić się z opinią autorki choćby dlatego, że za nowoczesny i przełamujący schematy można byłoby uznać raczej łacińsko-niemiecki podręcznik kompozytora Gregora Schnitzkiusa (Musices praecepta maxime necessaria Latino Germanica pro incipientibus illius artis collecta), wydany w I6I9 r. w Gdańsku i zawierający podobnie jak Ars et praxis zbiór jedynie podstawowych zasad, ale wprowadzający terminologię muzyczną w języku narodowym ${ }^{19}$. Nowatorską próbą unowocześnienia sposobu przekazu i szerszego upowszechnienia nauki muzyki m.in. dzięki zastosowaniu języka ojczystego była też wydana w Krakowie w I647 r. słynna Tabulatura muzyki abo Zaprawa muzykalna Jana Aleksandra Gorczyna, nie pomyślana wprawdzie jako podręcznik do nauki chorału, ale zawierająca w pierwszych rozdziałach wykład podstawowej wiedzy o muzyce, niezbędnej również do opanowania śpiewu kościelnego ${ }^{20}$.

To niewielkich rozmiarów dzieło napisane zostało w formie przypominającej katechizmowe pytania i odpowiedzi, niespotykanej w starszych łacińskich traktatach m.in. Sebastiana z Felsztyna, Marcina Kromera, czy Stefana Monetariusa. Zbliżona do Tabulatury formę miał też traktat Szymona Starowolskiego, Musices practicae erotemata, wydany w Krakowie w I650 r. ${ }^{21}$. Autor ten we wstępie uskarżał się na brak

17 Zob.: Sigismundus Lauxmin (I596-I670), s. XIX.

I8 A. Krzepkowska, Zygmunt Lauxmin, s. 65, 67.

I9 Por.: Barbara Przybyszewska-Jarmińska, Barok. Część pierwsza: 1595-1696, Warszawa 2006 (= Historia Muzyki Polskiej 3), s. 490.

20 Zob.: Jan Aleksander Gorczyn. Tabulatura muzyki abo zaprawa muzykalna, wyd. Jerzy Morawski, Kraków 1990 (= Monumenta Musicae in Polonia, seria D Bibliotheca antiqua).

2I Katechizmową formę miał też popularny niemiecki podręcznik szkolny Heinricha Fabera Compendiolum musicae pro incipientibus (Braunschweig I548), wielokrotnie wznawiany w różnych drukarniach i tłumaczony z łaciny na język niemiecki przez wielu autorów w XVI i XVII w., prawdopodobnie znany również w Polsce. Składał się on z dziesięciu rozdziałów prezentujących zagadnienia definicji muzyki, kluczy, głosów, śpiewu, mutacji, figur i znaków, ligatur, pauz, proporcji oraz tonów, 
dobrych kantorów, a nawet kleryków, którzy potrafiliby właściwie śpiewać psalmy, podobnie jak Lauksmin narzekał na brak dobrych i cierpliwych nauczycieli śpiewu chorałowego $^{22}$. Być może właśnie katechizmowa forma wspomnianych krakowskich druków skłoniła autorkę do uznania zwięzłego traktatu Lauksmina za tekst bardziej od nich nowoczesny, pomimo dużego podobieństwa przekazywanych treści. Wszak rozdziały od czwartego do czternastego w opracowaniu Starowolskiego oraz pierwsze cztery rozdziały Tabulatury muzyki dotyczą tych samych, podstawowych zasad muzyki oraz reguł solmizacji, jakie znalazły się w Ars et praxis, choć podane zostały w innej formie, bardziej nawet innowacyjnej w przypadku Gorczyna niż Lauksmi$n^{23}$. Krakowskie druki były jednak znacznie obszerniejsze i poruszały również inne zagadnienia, związane nie tylko z chorałem, ale w przypadku Tabulatury muzyki także z muzyką figuralną oraz instrumentalną. Pomimo różnorodnych niedoskonałości, podręczniki te wykorzystywano w nauczaniu choćby dlatego, że były szerzej dostępne, w przeciwieństwie do innych, przywoływanych również przez Krzepkowską, np. niewydanych drukiem siedemnastowiecznych zapisków Jana Brożka, profesora Akademii Krakowskiej, zainteresowanego raczej zagadnieniami teoretycznymi niż praktycznymi ${ }^{24}$. Z tych samych powodów w edukacji muzycznej nie były też używane zagraniczne prace jezuitów, opublikowane zanim ukazał się druk Ars et praxis musica. Musiały być one znane i studiowane w Polsce, skoro znalazły się w księgozbiorze Biblioteki Jagiellońskiej, ale ponieważ zawierały głównie rozważania o charakterze teoretycznym i spekulatywnym, a nie praktycznym ${ }^{25}$, to z pewnością nie stanowiły również wzorca dla traktatu Lauksmina. Z kolei o podręcznikach wykorzystywanych w XVII w. w klasztorach, które pielęgnowały często własne tradycje w zakresie przekazywania sztuki śpiewu chorałowego kolejnym pokoleniom zakonnic i zakonników, wiemy dziś niewiele, bo większość źródeł z tego okresu zaginęła. Opracowania ta-

zob.: Joel Lester, Between Modes and Keys. German Theory 1592-I802, New York 1989, s. 68-70. Być może ten właśnie podręcznik był inspiracją dla Gorczyna i Starowolskiego.

22 Por.: B. Przybyszewska-Jarmińska, Barok, s. 490-49ı. Lauksmin we wstępie do swojego wykładu, zatytułowanym „Ad Philomusum”, zamieścił następującą uwagę: „Po pierwsze, niewielu jest takich, którzy by potrafili czy też chcieli wykładać tę sztukę zwięźle i zrozumiale. Albowiem tak jak nauczyciele innych umiejętności, nie wiem jakim powodowani błędem, zwykle na początku obarczają uczniów trudniejszymi zagadnieniami, tak i nasi nauczyciele śpiewu od razu narzucają cantus fractus i wymuszają precyzję wykonania subtelnej melodii. Dlatego też mylących się chłopców poniżają, dręczą, nękają, w sposób godny pożałowania. A jednak po upływie pierwszego a nawet drugiego roku większego postępu nie widać", zob.: A. Krzepkowska, Zygmunt Lauxmin, s. 76. Opinia ta ukazuje nie tylko ówczesne problemy pedagogiczne i metodyczne, lecz także drugorzędny już status muzyki chorałowej, stopniowo wypieranej przez muzykę figuralną.

23 Por.: J.A. Gorczyn, Tabulatura muzyki; A. Krzepkowska, Zygmunt Lauxmin, s. 58-59; Maria Pamuła, „Pojęcie tonów i śpiewu kościelnego w «Musices Practicae Erotemata» Starowolskiego”, Muzyka I9 (I974) $\mathrm{nr}$ I, s. 55 .

24 Por.: A. Krzepkowska, Zygmunt Lauxmin, s. 59-6o; zob. też: B. Przybyszewska-Jarmińska, Barok, s. 493.

25 A. Krzepkowska, Zygmunt Lauxmin, s. 6o-6I. 
kie musiały jednak istnieć, a świadectwem tego jest choćby zachowany w bibliotece klasztoru oo. Karmelitów na Piasku w Krakowie tekst Instructio brevis pro addiscendo cantu chorali ${ }^{26}$. Biorąc jednak pod uwagę zachowane egzemplarze zakonnych podręczników osiemnastowiecznych, można stwierdzić, że Ars et praxis musica bliska była temu właśnie nurtowi.

We wstępie „Ad Philomusum” autor wspomniał o braku książek do nauki muzyki, co wskazuje, że nawet wydane drukiem krakowskie traktaty Gorczyna i Starowolskiego nie były powszechnie dostępne w całym kraju. Skoro jednak Lauksmin był w stanie napisać własny podręcznik, to znaczy, że zdobył wcześniej wiedzę w zakresie teorii muzyki i umiejętności praktyczne w nauce śpiewu, a stało się to najpóźniej podczas studiów w jezuickim nowicjacie i seminarium nauczycielskim ${ }^{27}$. Dowodem na znajomość innych, także dużo starszych traktatów muzycznych jest choćby taki sam sposób usystematyzowania wykładanych treści, a nawet sięgnięcie po wykorzystywane w wielu z nich, popularne przykłady graficzne obrazujące skale muzyczne, obecne choćby w szesnastowiecznych traktatach Sebastiana z Felsztyna i Marcina Kromera $^{28}$. Podstawowe zagadnienia, takie jak dźwięk, sylaby solmizacyjne i nauka solmizacji opartej na ukształtowanym w średniowieczu systemie heksachordalnym, skala muzyczna i clavis były prezentowane we wszystkich traktatach dotyczaccych $m u$ sica plana oraz we wstępnych rozdziałach podręczników do nauki muzyki figuralnej i instrumentalnej (np. u Gorczyna). Pod względem prezentowanych treści Ars et praxis musica, wbrew twierdzeniu Krzepkowskiej, była więc bardzo podobna do innych polskich traktatów z XVI i XVII w. ${ }^{29}$. Nowością nie był również zwięzły styl przekazu, bo już choćby u Marcina Kromera definicje i objaśnienia miały równie krótką i przejrzystą formę. Oryginalności traktatu Lauksmina przeczą też wyraźne reminiscencje fragmentów znanych wówczas druków muzycznych, które trudno uznać za przypadkowe. Przykładem tego jest np. metafora zwykłego klucza użyta do objaśnienia znaczenia kluczy muzycznych w Opusculum musices noviter congestum Sebastiana z Felsztyna (Kraków I524-25):

Clavis zaś stanowi otwarcie śpiewu, gdyż odsłania i ukazuje naturę każdego śpiewu działając na wzór rzeczywistego klucza; jak przy jego pomocy mamy dostęp do rzeczy ukrytych,

26 Ms. 6063 (324), papier, $65+9$ fol., wymiary: 19,5 x 15,5 cm, por.: Jerzy Gołos, „Muzykalia Biblioteki Klasztoru Karmelitów na Piasku w Krakowie", Muzyka II (1966) nr 3-4, s. 93. Traktat ten nie został jeszcze dokładnie przebadany i przetłumaczony na język polski, dlatego jego szczegółowa zawartość oraz autorstwo nie są znane.

27 Zob.: A. Krzepkowska, Zygmunt Lauxmin, s. 33 .

28 Zob. np. diagram ukazujący stopnie skali i odpowiadające im sylaby: Opusculum musicae compilatum noviter, w: Sebastian z Felsztyna. Pisma o muzyce, opr. i przekład Elżbieta Zaremba-Witkowska, Kraków I99I (= Monumenta Musicae in Polonia, seria C Tractatus de musica), s. 3I; Marcin Kromer, Musicae elementa, s. I4; skrócona i uproszczona wersja tego samego diagramu w traktacie Lauksmina: Sigismundus Lauxmin (1596-1670), s. I4.

29 Por.: A. Krzepkowska, Zygmunt Lauxmin, s. 65. 
w ten sam sposób otwierają się przed nami owe niewiadome i tajemne elementy skali muzycznej, to znaczy śpiew, ton i voces ${ }^{30}$.

I w analogicznej definicji w traktacie Lauksmina:

Podobnie jak w innych przypadkach używa się kluczy, aby otwierały to, co było zamknięte i aby istota tego ujawniła się, tak i w śpiewie klucze stosuje się po to, aby pokazywały w jakim miejscu znajdują się i mogą być wydobyte dźwięki muzyczne ${ }^{31}$.

Również zakończenie wstępu do Opusculum musicae compilatum noviter Sebastiana z Felsztyna (Kraków I517) z tradycyjną inwokacją i zapewnieniem, że ów wykład, skierowany do początkujących, jest prosty i zrozumiały:

Na chwałę przeto Błogosławionego Jezusa i Jego Niepokalanej Matki, na wieki i ponad wieki w dziewictwie trwającej Maryi, dla kształcenia nowicjuszy nieobeznanych z tą sztuką, jak potrafię najkrócej w łatwym i zrozumiałym stylu rozpoczynam wykład ${ }^{32}$,

przypomina deklarację zamieszczoną w zakończeniu wstępu do Ars et praxis:

Ogłaszamy więc tę łatwą metodę nauczania i aby brakowi podręczników zaradzić, chcemy w zwięzłej formie przedstawić to, co zwykło się śpiewać w kościele świętym, aby mogli się z tego uczyć ci, co zechcą i aby sami, z własnej woli, kiedy zechcą, śpiewać mogli33,

oraz inwokację na końcu traktatu:

A tymczasem niech to, co dotąd powiedziano, pomnaża chwałę Boga Najlepszego i Najwyższego oraz cześć Królowej Niebios i niebian, śpiewem nieustannie Boga wychwalającym ${ }^{34}$,

Oczywiście wileński podręcznik zawiera pewne elementy, które uznać można byłoby za oryginalne i nowatorskie, jak słusznie zauważa Krzepkowska (m.in. utożsamienie cantus fractus ze śpiewem menzurowanym wielogłosowym ${ }^{35}$, widocz-

30 Sebastian z Felsztyna, s. 79: „Est autem clavis cantus reseratio, quae cuiusque naturam cantus aperit et manifestat instar realis clavis se habens, qua perinde ac ad abditorum reclusionem pervenitur, sic illa occulta et incognito scalae musicae nobis reserantur, putta cantus, tonus et voces”.

3I Zob.: A. Krzepkowska, Zygmunt Lauxmin, s. 87: „Sicut in rebus aliis clavium unus est, ut aperiantur, quae occulsa erant, et appareant quid sint; ita in cantus sunt claves, quae ostendunt voces musicas in quonam loco sint et proferri possint. Sunt autem septem alphabeti literae, habentes adiunctas sibi duas vel tres voces. Ponuntur in scala ordine recto alphabeti sursum, deorsum vero retrograde, sic”.

32 Sebastian z Felsztyna, s. 28: „Ob gloriam igitur Iesu benedicti eiusque matris intemeratae, virginitate in aeternum et eltra manente Mariae, breviscule quo potuerim pro institutione noviciorum in hac arte non versatorum facili planoque stilo materiam principio”.

33 Zob.: A. Krzepkowska, Zygmunt Lauxmin, s. 76: „Ostendimus autem hunc facilem modum docendi, et ne deesset copia librorum, minoribus formis volumus subiicere ea, quae in Sancta Ecclesia decantari solent, ut et discerent in his, qui vellent, et vel ipsi soli, quando vellent, cantare possent".

34 Zob.: ibid., s. 90: „Interim haec dicta sint, Ad Maiorem DEI OPTIMI MAXIMI gloriam; nec non Reginae Coelorum et Coelitum, divinas Laudes perpetim canentium, honorem”.

35 Zob.: ibid., s. 66. Lauksmin odnosi ten termin do śpiewu menzurowanego wielogłosowego, tymczasem w piętnasto- i szesnastowiecznej praktyce muzycznej określano w ten sposób menzuralną interpretację zapisu neumatycznego lub elementy śpiewu menzurowanego włączane do kompozycji chorałowych jednogłosowych (cantus planus), zob. np.: Tadeusz Maciejewski, „Elementy systemu menzuralnego w monodii chorałowej XIII-XVI wieku”, w: Notae musicae artis. Notacja muzyczna w źródtach polskich 
na troska o przystępność wykładu i związane z tym uproszczenie oraz ograniczenie do niezbędnego minimum przekazywanych treści, a także konkretne zalecenia dotyczące sposobu przyswajania kolejnych partii materiału ${ }^{36}$ oraz niewystępujące w starszych traktatach wskazówki dotyczące praktycznej interpretacji zapisu neumatycznego ${ }^{37}$ ), ale jest on jednocześnie bardzo mocno osadzony w tradycji i nie wprowadza żadnych przełomowych, rewolucyjnych zmian.

\section{ZACHOWANE EGZEMPLARZE I RECEPCJA TRAKTATU}

Niewielewiadomo dziś na temat recepcji podręcznika Lauksminaw XVII iXVIIIw., poza tym, że przez co najmniej kilkadziesiąt lat korzystano z niego w Wilnie, o czym świadczą dwa wznowienia z I669 i I693 roku. W dostępnych opracowaniach brak informacji na temat wysokości kolejnych nakładów, nie wiadomo więc, jak duży miały one krąg odbiorców. Do naszych czasów zachowało się zaledwie kilka egzemplarzy ostatniego wydania. Druki te przechowywane są w Bibliotece Uniwersyteckiej w Wilnie ${ }^{38}$, w Bibliotece Narodowej w Warszawie ${ }^{39}$ oraz w Bibliotece Muzeum Narodowego im. Czartoryskich w Krakowie ${ }^{40}$. Odkrycie polskojęzycznego tłumaczenia z końca XVIII w. w nowym świetle ukazuje zasięg oddziaływania Ars et praxis musica. Traktat musiał cieszyć się znacznie większą popularnością, niż to wykazywano dotychczas w literaturze przedmiotu i był prawdopodobnie znany nie tylko na Wileńszczyźnie, ale być może również w kolegiach jezuickich w innych regionach Rzeczpospolitej. Nie jest też wykluczone, że użytkowano go także poza środowiskiem związanym z zakonem. Nie wiadomo, jakie były losy poszczególnych egzemplarzy przechowywanych w bibliotekach burs jezuickich po kasacie zakonu. Być może właśnie wtedy niektóre z nich trafiły do innych bibliotek, również tych odległych od Wilna. Jeden z druków musiał z pewnością znajdować się pod koniec XVIII w.

XI-XVI wieku, red. Elżbieta Witkowska-Zaremba, Kraków 1999, s. 29I-293; Lenka Hlávková, „Credo Settings in cantus fractus in Bohemian Sources. A Preliminary Report on a Neglected ars nova Repertory", w: Ars musica and its Contexts in Medieval and Early Modern Culture, red. Paweł Gancarczyk, Warszawa 20I6, s. 247-253.

36 Por.: A. Krzepkowska, Zygmunt Lauxmin, s. 65.

37 „Przechodząc do ćwiczeń z tekstem dodać należy co następuje: a mianowicie mieć na uwadze, że śpiewając tekst, sylaby tekstu chorałowego wypowiada się na nutach bez ogonków, na tych zaś z ogonkami sylaba dopiero co wygłoszona ulega wzdłużeniu. Jeśli znak taki ^ znajduje się nad którąkolwiek nutą, przypomina, że nutę tę należy trzymać nieco dłużej. Kropka . zaś dodana do nuty wskazuje, że tę nutę należy trzymać dłużej a następną krócej, zgodnie z akcentem języka łacińskiego”, cyt. za: A. Krzepkowska, Zygmunt Lauxmin, s. 8o.

38 Zob.: ibid., s. 63; Jürate Trilupaitienė podaje sygnaturę jednego z egzemplarzy wileńskich druków, który stał się podstawą edycji faksymilowej: sygn. III 10707, zob.: Sigismundus Lauxmin (I596-I670), s. VI.

39 Zob.: A. Krzepkowska, Zygmunt Lauxmin, s. 63. Traktat przechowywany jest pod sygnatura SD XVII.3.882 adl. i został udostępniony w repozytorium cyfrowym Polona: https://polona.pl/ search/?query=SD_XVII.3.882_adl.\&filters=public:I, dostęp I2 I 202I.

40 Zob.: B. Przybyszewska-Jarmińska, Barok, s. 186. 
w okolicach Limanowej, gdyż ze strony tytułowej polskojęzycznego tłumaczenia dowiadujemy się, że to właśnie tam, w 1798 r., wykonano przekład. Również duży stopień zgodności przetłumaczonej wersji z oryginałem (za wyjątkiem pominiętego wstępu), bezbłędnie skopiowane przykłady muzyczne, a nawet zbliżona kompozycja graficzna stron, wskazują wyraźnie na to, że limanowski tłumacz musiał dysponować oryginałem druku, gdyż do odręcznych odpisów zwykle zakradają się jakieś drobne odstępstwa, które ujawniłyby się także w kopii.

POLSKI PRZEKŁAD ARS ET PRAXIS MUSICA - CHARAKTERYSTYKA

\section{SZCZYRZYCKIEGO RĘKOPISU}

$\mathrm{Na}$ wewnętrznej stronie przedniej oprawy wklejona została (do góry nogami) inna, starsza karta tytułowa z inskrypcją: „Początki Choralne do książki Łacińskich Rudimentów Choralnych, zwłaszcza względem śpiewania przykładów i Tekstów, odwołujące się". Na dole strony zapisano informację, że tekst ten przepisano lub przetłumaczono „Na proźbę Jm Pana Kantego Rucinskiego”4I. Karta ta, stanowiąca już w czasie sporządzania rękopisu jedynie makulaturę wykorzystaną do oprawy oraz prób pióra i kaligrafii, jest zachowanym śladem po istnieniu innego jeszcze polskiego tłumaczenia łacińskiego traktatu chorałowego. Nie wiadomo, kim był Kanty Ruciński, być może lokalnym organistą lub nauczycielem śpiewu, który potrzebował przystępnych dla ówczesnej młodzieży materiałów dydaktycznych. Nic nie wskazuje wyraźnie na to, by osoba ta miała związek również z powstaniem przekładu Nauki i praktyki, choć oczywiście nie można tego wykluczyć. Nie wiadomo, czy jakieś relacje łączyły go z klasztorem cysterskim w Szczyrzycu, gdzie znalazł się później rękopis z tłumaczeniem traktatu Lauksmina.

Tytuł zapisany na karcie makulaturowej mógł odnosić się do krakowskiego druku z I76I r., Rudimenta Musicae Choralis, anonimowego autora (egzemplarz zachowany w Bibliotece Jagiellońskiej, sygn. I55350 II) ${ }^{42}$. Karta użyta do oprawy jest więc dowodem na to, że Ars et praxis musica nie była jedynym przetłumaczonym w tamtym czasie na język polski traktatem chorałowym. Być może w środowisku, w którym przekłady powstały, gromadzono różne dostępne materiały do nauki śpiewu chorałowego, np. w związku z ożywieniem działalności edukacyjnej w tym zakresie ${ }^{43}$.

4I Roman Nir błędnie podaje w obu cytowanych wcześniej artykułach, że dopisek, w brzmieniu zniekształconym zresztą przez niego: „przepisana na prośbę P. Kantego”, znajduje się na stronie tytułowej Nauki i praktyki, po dacie i miejscu wykonania tłumaczenia, por.: R. Nir, „Rękopiśmienne zabytki”, s. I04; R. Nir, „Rękopisy muzyczne”, s. 245.

42 Zob.: Alina Nowak-Romanowicz, Klasycyzm I750-I830, Warszawa 1995 (= Historia Muzyki Polskiej 4), s. 267.

43 Takich tłumaczeń i adaptacji starszych traktatów łacińskich mogło powstać więcej. Niestety aktualny stan badań oraz inwentaryzacji potrydenckich rękopisów chorałowych nie pozwala na razie na prześledzenie tego zjawiska. 


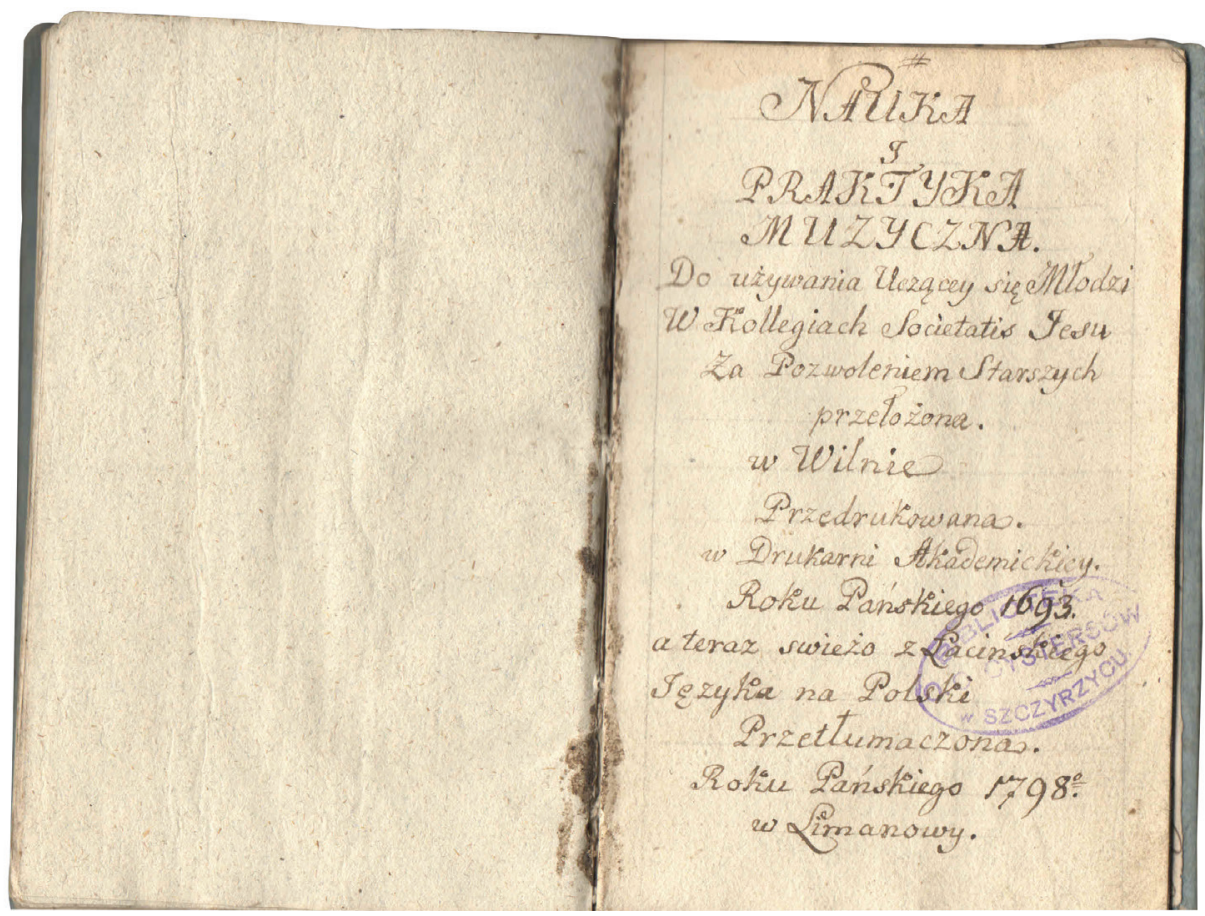

Il. 3. Strona tytułowa Nauki i praktyki muzycznej, I798, Biblioteka klasztoru oo. Cystersów, Szczyrzyc, sygn. S.II.8/2, fot. Biblioteka oo. Cystersów w Szczyrzycu

$\mathrm{Na}$ związek rękopisu ze szkołą wskazywałby również fragment papierowej karty z przełomu XVIII i XIX w., wklejony na wewnętrznej stronie tylnej oprawy, zawierający rękopiśmienny zapis łaciński dotyczący programu nauczania.

Tekst przekładu traktatu Lauksmina zmieścił się na czternastu stronach nieco mniejszych rozmiarów niż wileński druk, liczący zaledwie osiem kart nienumerowanych o wymiarach 155 x I86 mm ${ }^{44}$, co zbliża rękopis do objętości oryginału. Układ graficzny strony tytułowej rękopisu naśladuje stronę tytułową druku, u dołu dodano jedynie informację dotyczącą daty i miejsca sporządzenia tłumaczenia. W przekładzie na język polski brzmi on następująco: „Nauka i praktyka muzyczna. Do używania Uczącey się Młodzi W Kollegiach Societatis Jesu Za Pozwoleniem Starszych przełożona. w Wilnie Przedrukowana. w Drukarni Akademickiey. Roku Pańskiego I693. a teraz swieżo z Łacińskiego Języka na Polski Przetłumaczona. Roku Pańskiego 1798º. w Limanowy” (zob. il. 3). W polskojęzycznej wersji Ars et praxis musica pominięty został całkowicie wstęp „Ad Philomusum”. Być może nazbyt szczegółowe uwagi dotyczące ówczesnych realiów

44 Por.: Sigismundus Lauxmin (I596-I670), s. VI. 
nauczania muzyki, a także wspomniane już wcześniej podziękowania dla jednego z jezuitów, który opłacił pensję nauczyciela muzyki i zakup podręczników dla uczniów kolegium w Krożach, uznano już za nieadekwatne i zbędne, dlatego zdecydowano o skróceniu tekstu. Choć problemy edukacji muzycznej nie uległy zapewne w XVIII w. znaczącej poprawie, to z pewnością w ciągu dziesięcioleci zmienił się choćby stosunek do muzyki fraktowanej. Z aktualnego stanu badań wynika, że pod koniec XVIII w. dominowała już ona nad śpiewem chorałowym. Widać to też wyraźnie w podręczniku Antoniego Arnulfa Worońca z I8o6 r., który zasady „choralnego kantu” wyjaśniał już przez pryzmat muzyki figuralnej i w przeciwieństwie do Lauksmina oraz starszych autorów, przekonanych, że naukę muzyki rozpoczynać należy od chorału, twierdził:

[...] kiedy się jednak przekonywam, że w Kancie choralnym nie może bydź wydoskonalony ten, który nie zna figurału, połączyłem w tem dziele moiem początki tak figuralnego iako i choralnego kantu, spodziewając się, że Publiczności dogodnym się stanę ${ }^{45}$.

Tłumaczowi traktatu nieodpowiednie mogły się też wydawać krytyczne uwagi na temat agresywnych nauczycieli, których z pewnością wciąż nie brakowało. Powody decyzji mogły być różne, natomiast jej podjęcie wskazuje na to, że przekład miał służyć przede wszystkim do celów praktycznych, bo nie pominięto w nim żadnego z pozostałych ustępów tekstu, które odnoszą się już bezpośrednio do zasad muzyki. Skrócono jedynie końcową formułę z jezuickim wezwaniem „Ad Maiorem Dei Gloriam”, pomijając w niej wspomnienie o Królowej Niebios.

Z dużą dokładnością i bez istotnych błędów skopiowane zostały wszystkie znaki i przykłady muzyczne, co potwierdza, że tłumacz lub osoba wykonująca kopię tłumaczenia, dysponowali egzemplarzem druku Lauksmina, a nie jego odręcznym odpisem (il. 4) ${ }^{46}$. W rękopisie pominięto pełne zapisy muzyczne wokalnych wprawek solmizacyjnych oraz śpiewów $O$ adoranda Trinitas i fragmentów melodii Veni Sancte Spiritus, Sit nomen Domini, Sub Tuum Praesidium, Sancti Dei omnes, Qui passus es, Tibi laus, Tibi gloria, które miały służyć uczniom do wyćwiczenia prezentowanych w traktacie zasad. W odpowiednich miejscach zamieszczono jedynie ich incypity. Przyczyn dokonania skrótów mogło być kilka, ale z pewnością nie były one podyktowane brakiem materiału piśmienniczego, ponieważ nie wszystkie karty rękopisu zostały ostatecznie wykorzystane. Bardziej prawdopodobne jest, że adresat tłumaczenia posiadał oryginalny egzemplarz podręcznika, bądź dobrze znał śpiewy chorałowe i proste wprawki wokalne o schematach łatwych do zapamiętania.

45 Fragment dedykacji dla księcia Dominika Radziwiłła w: Antoni Arnulf Woroniec, Początki muzyki, tak figuralnego iako i choralnego kantu, Wilno I806, s. [VIII-IX] (nienumerowane), Biblioteka Uniwersytecka w Warszawie, sygn. 4.23.9.5I.

46 Błędów nie udało się natomiast uniknąć w tłumaczeniu Agnieszki Krzepkowskiej. W kilku miejscach zabrakło kluczy, a znaki chromatyczne i sylaby zostały przesunięte, co może prowadzić do błędnego odczytania przykładów, por.: A. Krzepkowska, Zygmunt Lauxmin, s. 78, 81, 82, 87. 


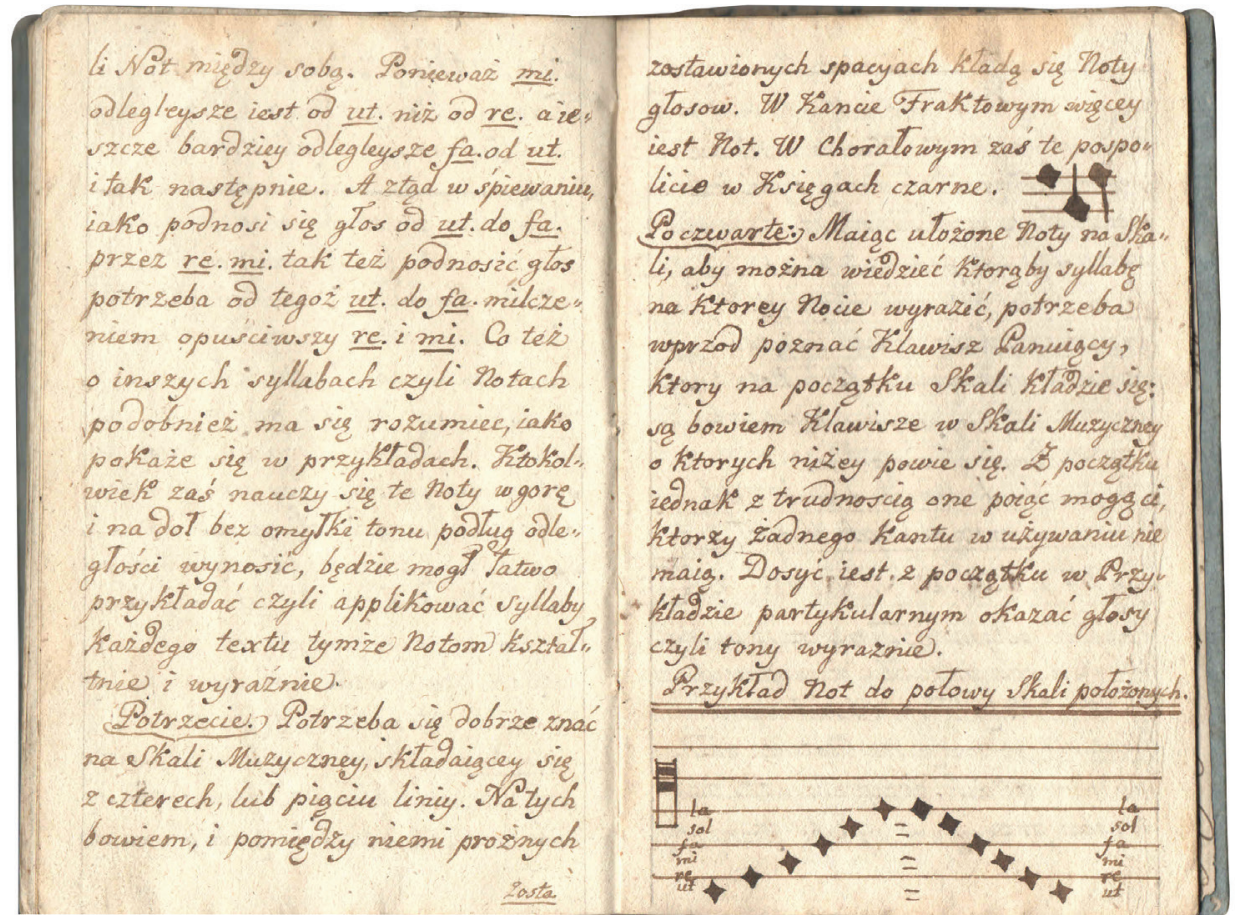

Il. 4. Fragment pierwszego rozdziału Nauki i praktyki muzycznej, 1798, Biblioteka klasztoru oo. Cystersów, Szczyrzyc, sygn. S.II.8/2, fot. Biblioteka oo. Cystersów w Szczyrzycu

Najwyraźniej tłumaczenie zostało sporządzone dla kogoś, kto nie był biegły w łacinie, ale opanował już w jakimś stopniu sztukę muzyczną, a więc raczej dla nauczyciela, niż dla uczniów.

Osiemnastowieczny przekład w porównaniu ze współczesnym, autorstwa Agnieszki Krzepkowskiej, okazał się być równie wierny oryginałowi, a w niektórych miejscach lepiej nawet oddający w polszczyźnie zawiłości siedemnastowiecznej łaciny. Na uwagę zasługuje jednak przede wszystkim terminologia muzyczna. Krzepkowska, trzymając się zasad przyjętych we współczesnych edycjach traktatów, zrezygnowała z tłumaczenia kluczowych pojęć, nie mających dosłownego odpowiednika we współczesnym języku polskim i teorii muzyki, natomiast pozostałe przetłumaczyła w ich dzisiejszym brzmieniu. Tymczasem limanowski tłumacz konsekwentnie stosował polskie odpowiedniki, będące niekiedy jedynie spolszczonymi wersjami słów łacińskich, czyli tzw. kalkami językowymi, np. „kant” w miejsce łacińskiego cantus, czyli „śpiew”47,

47 Gorczyn w swoim traktacie posługuje się polskim terminem „śpiew”, „śpiewanie”, a jedynie w rozdz. II Tabulatury wprowadza termin łaciński „cantus b mollaris”. Natomiast określenie „kant”, „kant choralny” pojawia się m.in. w rękopisie z przełomu XVIII i XIX w. zawierającym lamentacje (Biblioteka Uniwersytecka w Wilnie, fond 45, ms. 66), zob.: Jerzy Morawski, „Wileńskie podręczniki chorałowe”, 
pojawiający się w tytule pierwszego rozdziału: „Początki Pospolite Kantu Muzycznego Choralnego i Łamanego czyli Fraktu”, „klawisz” (zamiast „klucz”, łac. clavis), np. rozdział „O klawiszach /: Kluczach :/ Muzycznych”48, „skala” (w znaczeniu „linie” albo „nutownica”, łac. scala $\left.{ }^{49}\right)$ : „Potrzeba się dobrze znać na Skali Muzycznej składaiącej się z czterech, lub pięciu liniy”. W kilku innych przypadkach próbował tłumaczyć terminy łacińskie w sposób dosłowny, podobnie zresztą jak inni polscy autorzy tego czasu: „prożny plac” (pole między liniami, łac. spatium), „głosy not” (voces), „łamany” naprzemiennie z „fraktowany” lub „fraktowy” (fractus), „noty gałki nie ogonatki" "so (notas non caudatas), „ogonatki” (notas caudatas) ${ }^{\text {I }}$, np. „Syllaby Textu Choralnego wymawiać się powinny na Notach gałkach nie ogonatkach; przez ogonatki zaś trzeba przeciągać syllabę która się dopiero na gałce zaczęła”. W wielu miejscach użył też terminów przyjętych już wcześniej w języku staropolskim, np.: „choralny” 52 (chorałowy), „b czworgran” lub „wersał” (b quadratum)53. Klucze zaznaczane na początku systemów określił jako „klawisze oznaczające”, „panujące” lub „dominans” (claves signatae)54, a nieoznaczane na liniach: „klawisze skryte” (claves occultae): „Klawisze które się wyraźnie kładą, zowią się: Claves Signata, Klawisze Oznaczaiące, albo Dominans Panuiący Klawisz: a insze Occulta Skryte”. Niektóre z tych form językowych nie pojawiają się w znanych do tej pory traktatach polskojęzycznych, co czyni rękopis szczyrzycki interesującym świadectwem rozwoju i przemian polskiej terminologii muzycznej oraz istnienia w XVIII w. różnych jej wariantów.

Muzyka 39 (1994) nr 2, s. 27, 29. Terminy te znajdujemy również w Poczq̨tkach muzyki Worońca. Natomiast ks. Wacław Sierakowski w kilku miejscach wspomina o „chorale” i dwukrotnie przywołuje „cantus gregorianus”, zob.: X. Wacław Sierakowski, Sztuka Muzyki dla Mtodzieży Kraiowey, Kraków I795, t. I, s. 55 , t. II, s. 28 , 138 .

48 Gorczyn używa terminu łacińskiego clavis, objaśniając, że oznacza on dosłownie „klucz”. Termin „klawisz" pojawia się w Tabulaturze w znaczeniu współczesnym, jako element klawiatury. W podręcznikach dla benedyktyńskich nowicjuszek ze Staniątkek claves tłumaczone jest jako „klawisz”, por. Jakub Kubieniec, „Nauka muzyki choralnej u Panien Staniąteckich w XVIII wieku”, w: Ars musica and its Contexts in Medieval and Early Modern Culture, red. Paweł Gancarczyk, Warszawa 20I6, s. I20. Z kolei u Worońca i ks. Sierakowskiego konsekwentnie używany jest już termin „klucz”.

49 U Gorczyna termin ten pojawia się jeszcze w brzmieniu łacińskim scala. Woroniec używa zarówno terminu „skala muzyczna”, jak i dosłownego tłumaczenia „drabina”, a ks. Sierakowski „skala”.

50 Gorczyn nazywa je „ogonkowatymi”.

SI Oba terminy, „gołki” i „ogonatki”, występujące również u Sierakowskiego, krytykuje Woroniec postulując korzystanie z terminów łacińskich, wobec braku dobrych odpowiedników w polszczyźnie, zob.: A.A. Woroniec, Początki muzyki, s. 7.

52 Tej samej formy używa już Gorczyn oraz benedyktynki, zob.: J. Kubieniec, „Nauka muzyki choralnej”, s. II8.

53 W podręcznikach benedyktynek bemol nazywany jest po prostu „bemułem”, por.: ibid., s. I2O. U ks. Sierakowskiego pojawia się już termin we współczesnym brzmieniu: „bemol”.

54 Gorczyn wprowadza termin łaciński, objaśniając go jako „znak znaczący głos tonu”. 


\section{OKOLICZNOŚCI WŁĄCZENIA RĘKOPISU DO ZBIORÓW BIBLIOTEKI KLASZTORU}

\section{OO. CYSTERSÓW W SZCZYRZYCU}

Ponieważ spisany w Limanowej rękopis przechowywany jest od wielu lat w bibliotece szczyrzyckiego klasztoru oo. Cystersów, nie sposób nie zapytać o to, kiedy dołączony został do tamtejszych zbiorów i czy miał ewentualnie jakiś związek z działalnością oświatową zakonników. W roku I798, kiedy sporządzano przekład traktatu Lauksmina, Polska znajdowała się już pod zaborami, a władze austriackie prowadziły szeroko zakrojoną akcję kasat klasztorów, zwłaszcza kontemplacyjnych, które nie prowadziły „pożytecznej” dla społeczeństwa działalności zewnętrznej, np. edukacyjnej, opiekuńczej czy medycznej ${ }^{55}$. Część zakonów decydowała się więc na otwieranie szkól, szpitali i ochronek, aby uniknąć likwidacji swoich klasztorów. Podobną decyzję podjęli również cystersi ze Szczyrzyca. Działalność zorganizowanej przez nich szkoły udokumentowana jest w źródłach od I780 roku. Wiadomo, że od I784 r. zakonnicy prowadzili trzyklasową szkołę dla dzieci z okolicznych wiosek i uczył w niej m.in. Antoni Dąbrowski, który przyjął później posadę nauczyciela w Limanowej, a w Szczyrzycu zastąpiony został przez Pawła Skórzewskiego. O innych nauczycielach i Rucińskim, którego nazwisko pojawia się na karcie makulaturowej w oprawie Nauki i praktyki muzycznej, nie ma wzmianek w literaturze przedmiotu. W źródłach archiwalnych znajduje się tylko informacja, że w 1785 r. prefektem szkoły był o. Jan Kajetan Bańkowski. W I793 r. placówka została wyróżniona za wzorową działalność przez urząd cyrkularny w Nowym Sączu, co prawdopodobnie dodatkowo uchroniło klasztor przed kasatą ${ }^{56}$, choć w niektórych publikacjach można znaleźć błędne informacje na ten temat. Przytacza je w swoich artykułach m.in. Roman Nir, podając, że w I794 r. zakonnicy utracili prawo do przyjmowania nowicjuszy, ziemię i wiele dóbr ruchomych, a władze zaborcze wywiozły ze Szczyrzyca dużą część rękopisów i druków. Niektóre z nich miały trafić do Seminarium Duchownego w Tarnowie oraz do Biblioteki Uniwersyteckiej we Lwowie, a na miejscu pozostawiono rzekomo tylko fragment dawnego księgozbioru ${ }^{57}$. Informacje te zostały zweryfikowane przez Jolantę Marszalską, autorkę monografii poświęconej zbiorom Biblioteki oo. Cystersów w Szczyrzycu. Wyniki jej badań archiwalnych wskazują wyraźnie, że opactwo nie zostało nigdy skasowane, a jedynie przekształcone w przeorat poddany pod jurysdykcję opata klasztoru cysterskiego w Jędrzejowie (do I9I8 r.) i w związku z tym księgozbiór

55 Tomasz Kargol, „Cystersi w dobie kasat - przypadek Jędrzejowa i Szczyrzyca. Gospodarka klasztoru w Szczyrzycu w pierwszej połowie XIX w.", w: Dziedzictwo Wincentego Kadtubka. Cystersi - miasto region od średniowiecza do wspótczesności, red. Krzysztof Ślusarek, Kraków 2018, s. 27-57; Jolanta M. Marszalska, „Cysterskie szkoły w Szczyrzycu od I780 do lat trzydziestych XX wieku”, Biuletyn Historii Wychowania 30 (2013), s. 9; Piotr P. Gach, Kasaty zakonów na ziemiach dawnej Rzeczpospolitej i Ślaska I773-19I4, Lublin 1984.

56 Jolanta M. Marszalska, Biblioteka opactwa Cystersów w Szczyrzycu do końca XIX stulecia, Tarnów 2007, s. 8-9.

57 Por.: R. Nir, „Rękopiśmienne zabytki”, s. Ioo; R. Nir, „Rękopisy muzyczne”, s. 233. 
nie uległ rozproszeniu, choć znaczna część majątku klasztornego została rzeczywiście zajęta przez władze świeckie i sprzedana ${ }^{58}$.

W zachowanych inwentarzach klasztornej biblioteki sporządzonych w I826 i I869 r., obejmujących inkunabuły i starodruki ${ }^{59}$, nie pojawia się wzmianka o wileńskim druku Ars et praxis musica ani o innych drukach muzycznych, więc szczyrzyckie opactwo raczej nigdy nie było w posiadaniu oryginalnego podręcznika Lauksmina. Niestety brak analogicznych, dziewiętnastowiecznych inwentarzy ksiąg rękopiśmiennych uniemożliwia dokładniejsze ustalenie okresu, kiedy podręcznik do nauki chorału trafił do cysterskiego księgozbioru. Prawdopodobnie znajdował się w bibliotece już w okresie międzywojennym, kiedy to zachowane rękopisy zostały po raz pierwszy uporządkowane i opatrzone sygnaturami przez o. Stefana Pałamara ${ }^{60}$. Szczegółowy katalog rękopisów muzycznych został sporządzony dopiero w II poł. XX w. przez Romana Nira i opublikowany w przywoływanych już tutaj artykułach ${ }^{61}$. To właśnie w tych publikacjach po raz pierwszy pojawia się informacja o tym nieznanym polskojęzycznym podręczniku do nauki śpiewu chorałowego. Jednak nowy katalog, opracowany przez Jolantę Byczkowską-Sztabę i Elżbietę Wojnowską na podstawie wyników inwentaryzacji szczyrzyckich rękopisów, przeprowadzonej wraz z Jolantą Marszalską w 2002 r., nie wspomina już o Nauce i praktyce muzycznej, choć rękopis ten nadal przechowywany jest w tamtejszej bibliotece pod sygnaturą wskazaną przez Nira $^{62}$. Ani w monografii, ani w załączonym w niej nowym katalogu muzykaliów nie wyjaśniono przyczyny tego pominięcia. Można się jedynie domyślać, że decyzję taką podjęto z powodu jego obcej proweniencji i dołączenia do księgozbioru w znacznie późniejszym okresie. Najwyraźniej więc traktat przez pewien czas musiał znajdować się w innym ośrodku, być może w limanowskiej szkole bądź w prywatnym księgozbiorze tamtejszego nauczyciela muzyki. Karty rękopisu nie noszą śladów intensywnego użytkowania, widoczne jest na nich jedynie niewielkie zabrudzenie na górnym marginesie, które mogło powstać w wyniku zalania. Tekst nie był więc prawdopodobnie zbyt często czytany i regularnie wykorzystywany w pracy dydaktycznej, co jednak nie musi oznaczać, że nie odwoływano się do niego podczas lekcji. Mógł on służyć nauczycielowi jedynie jako pomoc w przygotowaniu własnej metody nauczania. Zapewne podstawowe treści zawarte w traktacie były dobrze znane osobie posiadającej już jakieś wykształcenie muzyczne. Jeżeli traktat nie należał pierwotnie do klasztoru i nie był używany przez tamtejszych zakonników, to hipoteza o przeznaczeniu do użytku szkolnego wydaje się najbardziej prawdopodobna.

60 Ibid., s. 65 .

6I Por.: R. Nir, „Rękopiśmienne zabytki”, s. IOo-IO5; R. Nir, „Rękopisy muzyczne”.

62 Zob.: J.M. Marszalska, Biblioteka opactwa Cystersów, s. 83-84, 349-366. 
NAUCZANIE ŚPIEWU CHORAŁOWEGO W OSIEMNASTOWIECZNEJ POLSCE

Zastanawiać może, dlaczego pod koniec XVIII w. sięgnięto po traktat wydany ponad sto lat wcześniej i zadano sobie trud dokładnego przetłumaczenia go na język polski. Można to wytłumaczyć jedynie brakiem dostępu do nowszych podręczników, bądź nawet do jakichkolwiek materiałów dydaktycznych. Wprawdzie w 1. 1795-96 w Krakowie ukazało się trzytomowe dzieło ks. Wacława Sierakowskiego, Sztuka muzyki dla mtodzieży krajowej ${ }^{63}$, ale nie zawierało ono wykładu na temat śpiewu chorałowego, nie miało też charakteru podręcznika w ścisłym tego słowa znaczeniu. Z kolei tekst dostępnego łacińskiego druku Ars et praxis musica, musiał być zbyt trudny lub zupełnie niezrozumiały dla uczniów, a być może także dla samego nauczyciela, skoro podjęto decyzję o przygotowaniu starannego przekładu na język polski, podobnie jak przetłumaczono lub zamierzano przetłumaczyć Rudimenta Musicae Choralis.

Niewiele dziś wiemy na temat innych podręczników i traktatów chorałowych spisywanych i wydawanych w XVIII wieku. W literaturze wspominana jest jedynie niewielka liczba rękopisów użytkowanych w poszczególnych klasztorach, prawdopodobnie nie funkcjonujących poza tymi wąskimi środowiskami. Są to m.in. opracowania tworzone na potrzeby nowicjuszek benedyktyńskich z klasztoru sandomierskiego: Principia albo początki należące uczacemu się śpiewania figuratu Marianny Moszyńskiej (I750 r., Biblioteka Wyższego Seminarium Duchownego w Sandomierzu $)^{64}$ oraz staniąteckiego: Muzyka choralna albo Chymnow y responsoryi na swięta i niedziele wedtug poznosci czasów krótkie zebranie (1753 r., Biblioteka pp. Benedyktynek w Staniątkach, Ms. 59), Początki horatu dla pp. Świeckich sposobiacych się do Zakonu napisane R.P. I769, których mają się z wielka pilnościq uczyć (Biblioteka pp. Benedyktynek w Staniątkach, Ms. 58), Dla ichmciów Panien Probantek Fundament albo początki choratu (XVIII w., Biblioteka pp. Benedyktynek w Staniątkach, Ms. 52), podręcznik bez tytułu (XVIII w., Biblioteka pp. Benedyktynek w Staniątkach, Ms. 50 ${ }^{65}$. Do tej grupy należą też pojedyncze egzemplarze rękopiśmienne z innych środowisk zakonnych: karmelitańskie Instructio brevis i Directorium choris (1739, Biblioteka oo. Karmelitów na Piasku w Krakowie, Ms. 742I (208/II)), dwie kopie Modus ponendi accentum (XVIII w., Biblioteka oo. Karmelitów na Piasku w Krakowie, Ms. 177 oraz Ms. 4635 (288/I4)), Modusponendiaccentum (I782, Biblioteka oo. Karmelitów na Piasku w Krakowie, Ms. 62/2I 292 ${ }^{66}$, paulińskie Principia cantus choralis (I782 r., Archiwum oo. Paulinów na Jasnej Górze, Ms. I-224) ${ }^{67}$, dwa podręczniki z kręgu księży misjonarzy z Łyskowa na Wileńszczyźnie z przełomu XVIII i XIX w.: Principia cantus (Biblioteka Uniwersytecka w Wilnie, Ms. 39) oraz Principia seu methodus abreviatia

63 Zob.: A. Nowak-Romanowicz, Klasycyzm, s. 267.

64 Por.: ibid., s. 267.

65 J. Kubieniec, „Nauka muzyki choralnej”, s. II8-II9.

66 Zob.: J. Gołos, „Muzykalia Biblioteki Klasztoru Karmelitów”, s. 93-94.

67 J. Kubieniec, „Nauka muzyki choralnej”, s. I2I. 
choralis cantus (Biblioteka Uniwersytecka w Wilnie, Ms. 4I) ${ }^{68}$, a także rękopisy liturgiczne zawierające wpisy z objaśnieniami podstawowych zasad muzyki i solmizacji: Instructio cantus choralis w karmelitańskim Processionale (I759 r., biblioteka klasztoru oo. karmelitów w Oborach, Ms. b.s. ${ }^{69}$, dwa antyfonarze dominikanów z Nieświeża ( 760 r., Biblioteka Uniwersytecka w Wilnie, Ms. 22 i 23), rękopis bernardynów z Trok (przełom XVIII i XIX w., Biblioteka Uniwersytecka w Wilnie, Ms. 55a), Processionale z klasztoru Kanoników regularnych w Bychowie Starym nad Dnieprem (I798 r., Biblioteka Uniwersytecka w Wilnie, Ms. 28), rękopis liturgiczny o nieznanej proweniencji z przełomu XVIII i XIX w. (Biblioteka Uniwersytecka w Wilnie, Ms. 43) oraz rękopis liturgiczny o nieznanej proweniencji, zawierający m.in. lamentacje, z przełomu XVIII i XIX w. (Biblioteka Uniwersytecka w Wilnie, Ms. 66) ${ }^{70}$. Podobnych tekstów spisywanych na użytek zakonów i konkretnych klasztorów istniało z pewnością dużo więcej, o niektórych wiemy dziś jedynie z inwentarzy i wzmianek w ówczesnej literaturze (do takich przykładów należy np. Manuale ecclesiasticum dominikanina Alana Macha $\left.{ }^{71}\right)$.

Drukiem ukazały się natomiast jedynie anonimowe Compendium regularum generalum cantus ecclesiastici regularis (Wilno I753, Typis S.R.M. Academ. Societatis Jesu) ${ }^{72}$ oraz wspomniane już Rudimenta Musicae Choralis anonimowego autora (Kraków I76I ${ }^{73}$. Z kolei w pierwszych latach XIX w. wydrukowano dzieło o. Antoniego Arnulfa Worońca Początki muzyki tak figuralnego jako i choralnego kantu (druk w Wilnie w I8o4 r., sam traktat napisany w I794 r. w Nieświeżu), zachowane do dziś w dwóch egzemplarzach: w Bibliotece Uniwersyteckiej w Wilnie oraz w Bibliotece Jagiellońskiej ${ }^{74}$.

O tym, że zasięg zarówno rękopiśmiennych, jak i drukowanych podręczników był raczej niewielki i lokalny, świadczyć może choćby to, że Woroniec uważał siebie za pierwszego autora piszącego o chorale gregoriańskim $\mathrm{w}$ języku ojczystym ${ }^{75}$. Wobec braku dobrych i powszechnie dostępnych podręczników, zarówno w języku łacińskim, jak i polskim, nie może dziwić, że korzystano z wszelkich pomocy dydaktycznych, jakie tylko znajdowały się w zasięgu ręki, nawet tych z poprzedniej epoki. Sytuacja ta w jakimś stopniu prawdopodobnie odzwierciedlała postępujący kryzys samego śpiewu chorałowego, zwłaszcza w środowiskach niezakonnych, ale

68 J. Morawski, „Wileńskie podręczniki”, s. 27-28.

69 Piotr Wiśniewski, „Processionale z klasztoru oo. Karmelitów w Oborach”, Liturgia Sacra 22 (2016) nr I, s. 165 , I7I.

70 J. Morawski, „Wileńskie podręczniki”, s. 27-31, 34.

7I Tadeusz Miazga, „Alan Mach - skryptor i kompozytor choralny XVIII wieku”, w: Studia Hieronymo Feicht septuagenario dedicata, red. Zofia Lissa, Kraków I967, s. 284-285.

72 Zob.: Sigismundus Lauxmin (I596-I670), s. XXIII.

73 Zob.: A. Nowak-Romanowicz, Klasycyzm, s. 267.

74 Ibid., s. 267, 287.

75 Ibid., s. 268. 
również miała wpływ na jego pogłębienie. Brak materiałów dydaktycznych musiał przekładać się na niski poziom nauczania muzyki chorałowej, co z kolei obniżało jakość śpiewu w kościołach. Wydaje się, że problem ten był jednak mniej dotkliwy w zakonach pielęgnujących tradycje liturgiczne, które samodzielnie starały się zaradzić brakom i dysponowały własnymi podręcznikami. Dzięki temu za murami klasztornymi śpiew chorałowy był wciąż żywy i przekazywany kolejnym pokoleniom nowicjuszy i nowicjuszek.

W tym szerszym kontekście rękopis z tłumaczeniem Ars et praxis musica przedstawia się jako świadectwo samodzielnych poszukiwań materiałów dydaktycznych oraz podejmowania na poziomie lokalnym starań o podtrzymanie lub ożywienie tradycji nauczania śpiewu chorałowego prawdopodobnie wśród młodzieży świeckiej. Zachowany przekład traktatu Lauksmina jest również, obok siedemnastowiecznej Tabulatury muzyki Gorczyna, osiemnastowiecznych podręczników benedyktynek i Sztuki muzyki ks. Sierakowskiego, jednym z najwcześniejszych tekstów teoretyczno-muzycznych w języku polskim, a więc zawierającym kształtującą się dopiero, polskojęzyczną terminologię muzyczną.

\section{PODSUMOWANIE}

Do stosunkowo krótkiej listy znanych nam dziś traktatów teoretyczno-muzycznych i podręczników do nauki chorału z XVII i XVIII w. można dopisać jeszcze jeden tytuł. Choć nie jest on dziełem oryginalnym, a jedynie przekładem z języka łacińskiego, to jednak stanowi z jednej strony dość zaskakujące świadectwo recepcji siedemnastowiecznego podręcznika Zygmunta Lauksmina w odległych krańcach Rzeczpospolitej (choć już pod zaborami) w końcu XVIII w., a z drugiej strony jest jednym z nielicznych zachowanych z tego okresu przykładów polskiej terminologii muzycznej, będącej dopiero w fazie tworzenia i rozwoju. Pośrednio rękopis odsłania też fragment realiów epoki i niezmiennych problemów dydaktycznych, zwłaszcza w zakresie nauczania śpiewu chorałowego, spowodowanych brakiem podręczników, co z pewnością przyczyniało się również do stopniowego wypierania go przez repertuar pieśni religijnych w języku narodowym, zwłaszcza w świątyniach diecezjalnych. Należy mieć nadzieję, że prowadzone w przyszłości kwerendy pozwolą odkryć więcej tego rodzaju świadectw, które będą uzupełniać i weryfikować naszą wiedzę na temat edukacji i praktyki muzycznej w tym okresie. 


\section{BIBLIOGRAFIA}

Domański, Wojciech. „Teoria muzyki w traktatach chorałowych Sebastiana z Felsztyna”. W: Musica Medii Aevi, red. Jerzy Morawski. T. 7, I84-249. Kraków: PWM, 1986.

Gach, Piotr Paweł. Kasaty zakonów na ziemiach dawnej Rzeczpospolitej i Ślaska I773-I9I4. Lublin: Redakcja Wydawnictw KUL, 1984.

Gołos, Jerzy. „Muzykalia Biblioteki Klasztoru Karmelitów na Piasku w Krakowie”. Muzyka II, nr 3-4 (1966): 86-97.

Hlávková, Lenka. „Credo Settings in cantus fractus in Bohemian Sources. A Preliminary Report on a Neglected ars nova Repertory”. W: Ars musica and its Contexts in Medieval and Early Modern Culture, red. Paweł Gancarczyk, 247-253. Warszawa: Liber Pro Arte, 2016.

Jan Aleksander Gorczyn. Tabulatura muzyki abo zaprawa muzykalna. Wyd. Jerzy Morawski. Warszawa, Kraków: Instytut Sztuki PAN, PWM, I990 (= Monumenta Musicae in Polonia, seria D: Bibliotheca antiqua).

Kargol, Tomasz. „Cystersi w dobie kasat - przypadek Jędrzejowa i Szczyrzyca. Gospodarka klasztoru w Szczyrzycu w pierwszej połowie XIX w.”. W: Dziedzictwo Wincentego Kadtubka. Cystersi - miasto - region od średniowiecza do wspótczesności, red. Krzysztof Ślusarek, 27-57. Kraków: Towarzystwo Wydawnicze „Historia Iagellonica”, 2018.

Królikowska, Anna. Profesorowie jezuickich seminariów nauczycielskich od XVI do XVIII wieku. Stownik biograficzny. Kraków: Wydawnictwo Naukowe Akademii Ignatianum w Krakowie, Wydawnictwo WAM, 2017.

Krzepkowska, Agnieszka. Zygmunt Lauxmin - traktat „Ars et praxis musica”. Warszawa: Wydawnictwo Naukowe Semper, 2012.

Kubieniec, Jakub. „Nauka muzyki choralnej u Panien Staniąteckich w XVIII wieku”. W: Ars musica and its Contexts in Medieval and Early Modern Culture, red. Paweł Gancarczyk, II7-I29. Warszawa: Liber Pro Arte, 2016.

Lester, Joel. Between Modes and Keys. German Theory 1592-1802. Stuyvesant, NY: Pendragon Press, 1989 (= Harmonologia Series 3).

Maciejewski, Tadeusz. „Elementy systemu menzuralnego w monodii chorałowej XIII-XVI wieku”. W: Notae musicae artis. Notacja muzyczna w źródtach polskich XI-XVI wieku, red. Elżbieta Witkowska-Zaremba, 283-347. Kraków: Musica Iagellonica, I999.

Marcin Kromer. Musicae elementa. Wyd. Elżbieta Witkowska-Zaremba. Warszawa: Instytut Sztuki PAN, 2019 (= Monumenta Musicae in Polonia, seria C Tractatus de musica).

Marszalska, Jolanta M. „Cysterskie szkoły w Szczyrzycu od I780 do lat trzydziestych XX wieku”. Biuletyn Historii Wychowania 30 (2013): 7-23.

Marszalska, Jolanta M. Biblioteka opactwa Cystersów w Szczyrzycu do końca XIX stulecia. Tarnów: Wydawnictwo Diecezji Tarnowskiej - Biblos, 2007.

Miazga, Tadeusz. „Alan Mach - skryptor i kompozytor choralny XVIII wieku”. W: Studia Hieronymo Feicht septuagenario dedicata, red. Zofia Lissa, 284-297. Kraków: PWM, 1967.

Morawski, Jerzy. „Wileńskie podręczniki chorałowe”. Muzyka 39, nr 2 (1994): 27-46.

Nir, Roman. „Rękopisy muzyczne w Bibliotece oo. Cystersów w Szczyrzycu”. Archiwa, Biblioteki i Muzea Kościelne 37 (1978): 233-248.

Nir, Roman. „Rękopiśmienne zabytki muzyczne w niektórych polskich bibliotekach klasztornych". Muzyka 90, nr 3 (1978): 95-I09.

Nowak-Romanowicz, Alina. Klasycyzm 1750-1830. Warszawa: Sutkowski Edition, I995 (= Historia Muzyki Polskiej 4). 
Pamuła, Maria. „Pojęcie tonów i śpiewu kościelnego w «Musices Practicae Erotemata» Starowolskiego". Muzyka 23, nr I (1974): 54-68.

Przybyszewska-Jarmińska, Barbara. Barok. Część pierwsza: 1595-I696. Warszawa: Sutkowski Edition, 2006 (= Historia Muzyki Polskiej 3).

Sebastian z Felsztyna. Pisma o muzyce. Wyd. Elżbieta Witkowska-Zaremba. Kraków: PWM, I99I (= Monumenta Musicae in Polonia, seria C: Tractatus de musica).

Sierakowski, Wacław. Sztuka Muzyki dla Mtodzieży Kraiowey. Kraków: Drukarnia Szkoły Głównej Koronnej, I795-96.

Sigismundus Lauxmin (I596-I670), Ars et praxis musica. Graduale pro exercitatione studentium. Antiphonale ad Psalmos. Wyd. Jūratė Trilupaitienè. Warszawa: Wydawnictwo Naukowe Sub Lupa, 2016 (= Fontes Musicae in Polonia, B/I).

Trilupaitienè, Jūratė. „Zygmunt Lauksmin w życiu muzycznym Akademii Wileńskiej”. Muzyka 36, nr I (I99I): IOI-II5.

Wiśniewski, Piotr. „Processionale z klasztoru oo. Karmelitów w Oborach”. Liturgia Sacra 22, nr I (2016), s. I65-I75.

Witkowska-Zaremba, Elżbieta. Ars musica w krakowskich traktatach muzycznych XVI wieku. Kraków: PWM, 1986.

Woroniec, Antoni Arnulf. Początki muzyki, tak figuralnego iako i choralnego kantu. Wilno: Drukarnia Józefa Zawadzkiego, I806.

THE I798 POLISH TRANSLATION OF SIGISMUNDUS LAUXMIN'S ARS ET PRAXIS MUSICA AND ASPECTS OF PLAINCHANT TEACHING ON THE TERRITORY OF SEVENTEENTHAND EIGHTEENTH-CENTURY POLAND

The handwritten copy of a hitherto unknown Polish-language plainchant handbook held in the Cistercian Fathers' Library in Szczyrzyc (shelf mark S.II.8/2), produced in 1798 in Limanowa and entitled Nauka y praktyka muzyczna do używania uczacey się mtodzi $w$ Kollegiach Societatis Jesu za pozwoleniem starszych przetożona $w$ Wilnie [The teaching and practice of music for the use of pupils of Jesuit colleges, translated in Vilnius with the permission of superiors] has been identified by the author of this article as a translation of the Jesuit Sigismundus Lauxmin's handbook Ars et praxis musica. The latter was first published in 1667 in Vilnius, and later reissued twice (1669, I693). Its reception has not been studied thus far. Of the three editions, only several copies have come down to us. The discovery of a Polish translation made during the last years of the eighteenth century, more than a hundred years after the print's last edition, sheds new light on the history of the handbook and its impact, which extended beyond Jesuit circles and the Baroque era, and also on aspects of plainchant teaching during the early nineteenth century. Lauxmin's treatise was addressed to pupils and students as an aid to mastering the practice of plainchant. The author included no theoretical commentary and limited himself to the absolute basics, as well as practical methodological guidelines. The Polish translation was prepared in a different historical reality and is one of the relatively few surviving examples of how Polish musical terminology took shape and evolved during the eighteenth century. Indirectly, it also represents the state of musical educa- 
tion at the time and shows that, due to the lack of contemporary handbooks, teachers turned to educational aids from the previous era, adapting them for their current local needs.

Translated by Tomasz Zymer

Słowa kluczowe / key words: Zygmunt Lauksmin SJ, Ars et praxis musica, teoria muzyki / music theory, nauczanie muzyki / music education, chorał gregoriański / Gregorian chant, cystersi / the Cistercians, Szczyrzyc

Dr Dominika Grabiec, muzykolożka i italianistka, od 2008 r. pracuje w Instytucie Sztuki PAN, gdzie w ramach Katalogu Źródeł Muzycznych przygotowuje m.in. bibliografię ikonografii muzycznej w Polsce oraz bazę danych polskich potrydenckich rękopisów chorałowych. W 2017 r. uzyskała stopień doktora nauk o sztuce na podstawie dysertacji pt. Przedstawienia Pasji $w$ malarstwie wtoskim od XIII do XV w. Próba interpretacji symboliki trąb i rogów. Od 2017 r. współpracuje z Instytutem Historii Nauki PAN w ramach projektu Manuscripta.pl. Jej główne dziedziny badań to ikonografia muzyczna, średniowieczna kultura muzyczna oraz rękopisy liturgiczno-muzyczne. dominika.grabiec@ispan.pl

\title{
Monografia projektu HERA ,Sound Memories"
}

\author{
Antonio Chemotti \\ The Hymnbook of Valentin Triller (Wrockaw 1555). \\ Musical Past and Regionalism in Early Modern Silesia
}

\author{
zamómienia: vydawnictwo@ispan.pl
}

